\title{
'Ireland is Not Going to Take Her Orders from Rome': Leo XIII, Thomism, and the Irish Political Imagination
}

\author{
Rose Luminiello \\ (School of Divinity, History and Philosophy, University of Aberdeen, Aberdeen, UK) \\ rose.luminiello@abdn.ac.uk
}




\begin{abstract}
:
This article explores the extent to which the traditional Catholic philosophies of Thomas Aquinas influence the Irish political imagination in the nineteenth century. It looks first to Pope Leo XIII, one of the leading proponents of restoring Thomism into mainstream Catholic political thought, and the author of the influential encyclical Rerum Novarum (1891). The article examines how the Irish Land War during the 1880s influenced the development and audience of the encyclical. Finally, it analyzes how the Thomistic principles which served as the foundations of Rerum Novarum were used by the lower-class Irish Catholic laity to legitimize incidences of protest and resistance which were considered morally illicit by the Catholic Church. In doing so, the article demonstrates how Catholicism and Thomistic philosophy influenced the way in which Irish Catholics perceived their relationship with the state and their rights as citizens.

Keywords: Irish political thought, Land War, protest and resistance, Rerum Novarum, Pope Leo XIII, Thomism
\end{abstract}

\title{
Word count: 11,812
}


The Irish political imagination developed extensively during the late nineteenth century, influenced, among other things, by the mobilization of popular politics in the Land War and the inception of boycotting. ${ }^{1}$ As resistance to the status quo of Irish landlordism rose during the 1880s, divisions in the Irish Catholic Church with Rome also grew wider and more discordant. The Irish Land War saw tenant farmers and others engaged in a struggle with landlords over their rights to security and possession of the land. While many of the Irish bishops, such as Archbishop Thomas Croke of Cashel and Bishop Francis MacCormack of Anchory, supported the aims of the Land and National Leagues and a few, like Bishop Laurence MacEvilly of Elphin, did not, Rome viewed the Irish Land War as part of a growing, popular turn towards socialism and the dismantling of both state and church authority. As discontent grew amongst the lower-class Irish Catholic laity, so too did public incidences of protest and resistance which was considered morally illicit by the Church.

Rome's concerns over the situation in Ireland in the late nineteenth century would prove formative to Pope Leo XIII's development of his seminal 1891 encyclical, De Rerum Novarum: On Capital and Labour (known simply as Rerum Novarum). The text of Rerum Novarum relied heavily on a Thomistic political philosophy, which in some respects already shaped the Irish Catholic understanding of the political community before 1891, but which were more prominently brought into the public sphere by the encyclical. The sections of Rerum Novarum which dealt with the mutual responsibilities of the state and the political community in particular caused a key shift within Ulster's politically active Catholic community. The province's complex history of confessional tension between - broadly speaking - Catholics and Protestants and their respective claims to land, governance, and social autonomy (often from one another) frequently resulted in situations wherein Catholic protest and resistance were framed as just actions against an illegitimate, Protestant state using the language of the Rerum Novarum. Through its public presentation of Thomistic political thought, the encyclical ultimately influenced how the lower class Irish laity would come to view the responsibilities of the state in relation to the rights of the people, serving as a foundational language with which the Irish Catholic laity legitimized public protest and resistance when it conflicted with the morality upheld by the Church.

\footnotetext{
${ }^{1}$ Andrew Phemister, "“The Surging Tide of Pauper Democracy": Irish Boycotting and Anglo-American Liberalism', Radical History Review 134 (2019): 29-57.
} 
The ability to redefine or legitimize moral action amongst the laity themselves fundamentally shifted how Catholic society interacted with the institutional Church and with Catholicism as an active faith. Encyclicals on the issues of governmental or state legitimacy, the rights of the people, and the nature of the state had all been written prior to Rerum Novarum many of them, in fact, authored by Leo XIII and his advisors. What was different about 1891 that would make Rerum Novarum so influential was the presentation of Catholic traditional philosophies in a widely published papal encyclical addressed specifically to a popular Catholic audience. Prior to 1891, working and lower class Catholics tended to rely heavily on the clergy for the determination of morality, but the introduction of traditional Catholic philosophical principles directly into the public sphere shifted the ideological dynamics of Irish society away from Church control, placing the language of the Church at the disposal of the lower-class laity. ${ }^{2}$

So too, Leo's experience with the Irish situation would prove foundational to two aspects of Rerum Novarum: the tone and audience of the encyclical and its opposition to socialism. The developments in the Irish Land War during the 1880s had profound effects not simply upon the Church in Ireland, fraught with internal divisions, but on the international Church. The breakdown in Roman authority exemplified by the widespread disregard shown to the papal decree against boycotting, Saepe Nos, in 1888 and a subsequent papal reprimand would shape the future of Leo's interactions with the laity in Rerum Novarum. The inclusion of certain principles in the encyclical was a direct result of Leo's interests in the Irish situation, just as the Irish political imagination would be affected by the encyclical. The Irish Land War thus enabled a reciprocal relationship between Rome and Ireland.

This article seeks to understand the development of Irish Catholic political thought in the late nineteenth century, and in particular how the writings of Leo XIII encouraged Irish engagement with a distinct mode of Thomistic political thought. To do this, it will first be necessary to examine the core principles of Thomistic political thought and their influence on Leo XIII. The influence of Thomism on the relationship between the Irish Church and Rome in the 1880 s and 1890 s has not featured in the otherwise comprehensive literature dedicated to that

\footnotetext{
2 This article will not address the questions of individual morality as, to a certain extent, an individual always has the right to determine morality for themselves through their conscience in Catholicism, albeit within a certain moral framework. Unless otherwise indicated, the morality discussed here will refer solely to actions taken for the community or done communally and within the public sphere.
} 
relationship. ${ }^{3}$ Ambrose Macaulay, for example, in his book on the Holy See's interest in the Land War, does not consider how Irish events might have impacted upon both Leo and the drafting of Rerum Novarum, nor how Thomistic and neo-Thomistic concepts were applied to Irish circumstances. ${ }^{4}$ This article seeks to fill that gap by situating Rerum Novarum in both its intellectual and its practical contexts, both Irish and Roman. It was this fusion of the practical and the philosophical that provided many of the Irish laity with the philosophical tools to justify their methods of protest and resistance despite their apparent prohibition by the institutional Church.

\section{Thomism and Leo XIII}

Pope Leo XIII is often considered to be a reactionary, much like his immediate predecessor Pius IX and Leo's own mentor, Gregory XVI. There is no doubt that Pius IX was staunchly antimodernist, nor that Leo played a significant role in Pius's attacks on liberalism in Quanta Cura and the Syllabus of Errors while he held the position of Archbishop of Perugia. ${ }^{5}$ Leo's education under the Jesuits in Rome, both as a novice and then later in their school which trained nobles and clergy for the Holy See's diplomatic corps, also lends itself to the argument that he was deeply conservative, since the order was known for reactionary political views. This reading of Leo as situated firmly in traditionalist camps underestimates his papal writings, however, and his intention to respond to modernism rather than react against it entirely.

In his writings, Leo relied upon the Thomistic account of civil society as the foundational principle of Christian societies. Firstly, it is important to note that the Thomistic scheme of civil society relied upon the concept of the primacy of divine law over secular or human law, from

\footnotetext{
${ }^{3}$ See for example Emmet Larkin, The Roman Catholic Church and the Plan of Campaign in Ireland 1886-1888 (Cork University Press: 1978); The Roman Catholic Church in Ireland and the Fall of Parnell (University of North Carolina Press: 2011); 'Socialism and Catholicism in Ireland', Studies: An Irish Quarterly Review, 74, no. 293 (Spring 1998), 57-70. Thomas J. Morrissey, William J. Walsh, Archbishop of Dublin, 1841-1921 (Dublin: Four Courts Press, 2000). John Privilege, Michael Logue and the Catholic Church in Ireland, 1879-1925 (Manchester University Press: 2009). Mark Tierney, Croke of Cashel: The Life of Archbishop Thomas William Crooke 18231902 (Dublin: Gill and Macmillan, Ltd., 1976); Karina Urbach, 'On Her Majesty's Secret Service: Gladstone, Ireland and Pope Leo XIII, 1881-1885/86' in Vincent Viaene (ed.) The Papacy and the New World Order: Vatican Diplomacy, Catholic Opinion, and International Politics at the Time of Leo XIII, 1878-1903 (Brussels: Institut Historique Belge de Rome, 2005), pp. 181-194.

${ }^{4}$ Ambrose Macaulay, The Holy See, British Policy, and the Plan of Campaign in Ireland, 1885-1893 (Dublin: Four Courts Press, 2002).

${ }^{5}$ Owen Chadwick, A History of the Popes, 1830-1914 (Oxford: Oxford University Press, 1998), 277. See also
} 
which hinges the legitimacy of state authority, and the rights and duties of citizens. In this reading, divine law is necessarily the ultimate form and source of all authority, as it derives from an omnipotent divine being; thus divine law takes precedence as human law derives its truth or righteousness from the immutably good nature of the divine. ${ }^{6}$ In this understanding, any government which enacts a law that contradicts the divine law - which can be found in the Bible and for Catholics in the teachings and traditions of the Church-delegitimizes its own authority.

The legitimacy of state authority and the primacy of divine law over human law is key to understanding Catholic lay disobedience to the state. In the Thomistic tradition and in Leo XIII's writings, Catholic citizens are not obliged to obey any law which is contrary to divine or natural laws nor to obey an illegitimate authority. For his part, Aquinas argued that 'Human law has the nature of law in so far as it partakes of right reason; and it is clear that, in this respect, it is derived from the eternal law. But in so far as it deviates from reason, it is called an unjust law, and has the nature, not of law but of violence. ${ }^{7}$ In the context of Catholic teaching, which holds itself to be the only true religion and arbiter of morality, any law which contradicts a Catholic teaching or restricts the practice of a Catholic teaching would be contrary to right reason and justice, and would thereby, Aquinas concludes, constitute an unjust law which does not require obedience. Leo similarly argued this point in his encyclical Dituturnum (1881), when he stated that Catholics could disobey the state "when anything is demanded of them which is openly repugnant to the natural or the divine law'. ${ }^{8}$ Thus in the Thomistic and neo-Thomistic accounts of the role of the state and the rights of citizens which underpin Rerum Novarum, the state is obliged to protect the free practice of religion, or to at least provide scope for its citizens to practice their religion without infringement either by the state or by other citizens. From this is derived an understanding that Catholic citizens are dutybound to obey the state even where it is not a Catholic majority democracy or a theocracy, yet they are not obliged to obey those laws which contradict or somehow limit Catholicism. ${ }^{9}$ When the state fails to protect the right to free practice of religion, or it actively works against religion, then it contradicts divine law and has

\footnotetext{
6 Thomas Aquinas, Summa Theologica, (New York: Benzinger Brothers, 1947), I.II, q. 93, a. 1

${ }^{7}$ Ibid., q. 93 , a. 3.

${ }^{8}$ It should be noted here that 'natural' law is considered in Thomism to be inherently in harmony and derived from divine law, and can therefore never contradict divine law, though natural law is considered to constitute imperfect knowledge (Ibid., q. 94). Pope Leo XIII, 'Diuturnum: On the Origins of the Civil Society', 29 June 1881, trans. Claudia Carlen, The Papal Encyclicals, 1878-1903 (Raleigh, N.C.: McGrath Publishing Company, 1981) pt. 15. All subsequent encyclicals written by Leo XIII will be taken from this book.

${ }^{9}$ Pope Leo XIII, 'Immortale Dei: On the Christian Constitution of States' 1 November 1885, pt. 4.
} 
proven its authority to be illegitimate. Philosophically, Aquinas draws this concept from Aristotle's understanding of the politeia, in which the classical philosopher defines the proper end of politics or the political community as human flourishing. ${ }^{10}$

Leo upheld these accounts of the divine and human laws, the legitimacy of state authority, and the duties and rights of citizens throughout his papacy. In Diuturnum, the Pope maintained, as had Aquinas, that a hierarchy of power was necessary to establish the common good and ensure its pursuit. ${ }^{11}$ In an earlier encyclical, Quod Apostolici Muneris (1878), the Pope further identified socialism as the greatest evil in society. His argument was not particularly concerned with economics, but rather condemning socialism because it sought to subvert a proper hierarchy of authority and because it challenged the human right to the ownership of private property and thereby constituted theft. ${ }^{12}$ Though the themes of private property and theft would arise again throughout various encyclicals which dealt with or were informed by the Irish Land War, the destruction of authority in society was Leo's primary concern when dealing with socialism. $^{13}$

The reasons for this are varied. First, the Pope wished to restore his temporal power in Italy, something he worried would be compromised by the threat of socialist uprisings or masonic conspiracies, the latter of which he blamed for the very existence of socialism and communism. Second, the papacy's perceived position as a moral authority and the Pope's ability to exert any influence over politics and governance also relied on the maintenance of a hierarchical authority in society, without which the Church would have no value to a government. Third, Leo's obsession with Thomistic philosophy made him incapable of accepting a society not based on a hierarchy of authority, as Aquinas maintained that such a hierarchy was necessary, both as a reflection of the hierarchy in divine law and as a necessary control on the evil tendencies of human nature.

Which type of governance or society would be legitimate, however, Leo does not clearly define. Though he and other nineteenth-century popes have been described as maintaining that

\footnotetext{
${ }^{10}$ Aristotle, Politics, trans. Benjamin Jowett, (Memphis: General Books, 2010), III.6.1278b17-24, 9.1280b39; VII.2.1325a7-10. Aristotle also refers to this as 'the good life' or 'happiness'.

${ }^{11}$ Leo XIII, Diuturnum, pt. 4; Katherine Archibald, 'The Concept of Social Hierarchy in the Writings of St. Thomas Aquinas' The Historian 12, no. 1, (Fall 1949): 4-9.

12 Pope Leo XIII, ‘Quod Apostolici Muneris: On Socialism’, 28 December 1878, pts. 2 \& 9.

${ }^{13}$ See for example, Pope Leo XIII, 'Humanum Genus', 20 April 1884, trans. Claudia Carlen, The Papal Encyclicals, 1878-1903 (Raleigh, N.C.: McGrath Publishing Company, 1981); 'Quod Auctoritate', 22 December 1885, trans. Claudia Carlen, The Papal Encyclicals, 1878-1903 (Raleigh, N.C.: McGrath Publishing Company, 1981.
} 
divine right monarchy or theocracy were the only true forms of governance, Leo insisted that there were other forms of just governance so long as the ability of Catholics to practice their religion was not restricted. ${ }^{14}$ In reintroducing and emphasising the Thomistic reading of the 'common good' of the political community, Leo attempted to make space in Catholic societies for modern ideas concerning governance and state authority. He followed Aquinas's argument that the individual in the political community must serve the common good, which was determined by the political community as a whole, and the pursuit of which was safeguarded by the state. ${ }^{15}$ Aquinas's distinction that the state did not determine the common good but only protected the community's ability to determine and pursue that common good would be at the heart of Rerum Novarum.

This concept of the common good and the relationship between the political community and the state had a particular impact on the laity of late nineteenth-century Ireland. Aquinas argued that a state which did not allow for the political community to pursue the common good was a state which delegitimised its own authority. In his discourse on kingship, De Regno (1267), Aquinas articulated this point clearly: 'If, therefore, a multitude of free men is ordered by the ruler towards the common good of the multitude, that rulership will be right and just, as is suitable to free men. If, on the other hand, a rulership aims, not at the common good of the multitude, but at the private good of the ruler, it will be an unjust and perverted rulership.' 16 Following this line of thought and combining it with Aquinas's other comments on freedom to practice religion and the right to private property, the common good Leo usually defined in his writings was the ability of Catholics to practice their religion freely and the citizen's right to private property. The Pope's insistence on the free practice of religion is unsurprising when one considers the various states with which he continued diplomatic ties, such as Prussia, where Otto von Bismarck had begun a campaign directed primarily against Polish Catholicism. ${ }^{17}$

The second element of the common good which Leo regularly emphasised, the right to private property, was a simple reiteration of a Thomistic argument. Aquinas argued that private

\footnotetext{
${ }^{14}$ Leo XIII, Immortale Dei, pt. 4. For more on how Leo's concept of the relationship between church and state evolves throughout his papacy, see John Courtney Murray, S.J., 'Leo XIII: Separation of Church and State', Theological Studies 14 (June 1953): 145-214. See also Samuel J. Thomas, 'The American Press and the ChurchState Pronouncements of Pope Leo XIII,' U.S. Catholic Historian 1, no. 1 (Fall, 1980): 17-36.

${ }^{15}$ Leo XIII, Immortale Dei, pts. 3, 5, \& 18.

16 Thomas Aquinas, De Regno ad Regem Cypri: On Kingship to the King of Cyprus, trans. Gerald B. Phelan (Toronto: The Pontifical University of Mediaeval Studies, 1949), pt. 10.

${ }^{17}$ Lech Trzeciakowski,
} 
property was necessary in a society in order to ensure the ultimate, temporal common good peace. Peace was considered by Aquinas to be essential in a community so that each member could focus their energies on attaining the ultimate end of heaven after their deaths. Without peace, the individual was distracted by temporal concerns. Aquinas argued that it was easier to ensure peace in the community if each individual owned their own property and could therefore provide for themselves; the hierarchy of society supported this system by providing a structure in which each man worked to his talents and ability rather than to a simple need. Leo held firmly to these ideas - in part as a reaction to the seizure of papal lands during the Risorgimento and the socialistic tendencies of the Italian Unification movement - and his encyclicals systematically upheld what Aquinas viewed as the intertwined principles of man's right to private property and social hierarchy.

In 1879, in an encyclical titled Aeterni Patris (On the Restoration of Christian Philosophy), for example, Leo argued that the heights of human perfection in philosophical thought had already been attained by Aquinas, the 'Angelic Doctor'; that Thomistic philosophy and theology should be considered as doctrine by virtue of its place within the traditional corpus of Catholic teaching; and that any attempt to expand or develop Aquinas's work would be mere erudition. ${ }^{18}$ Joe Holland has argued that for Leo, Thomism was a 'fundamental philosophical instrument' that corrected modern culture and liberalism in their essence by addressing the fragmentation of the subject (the person or the community) and the object (the common good, or ultimately, the Beatific Vision). ${ }^{19}$

Aquinas's account of the political community would become the foundation of all of Leo's philosophical thought and writings, from encyclicals, working letters to the hierarchy (circolari), and in his personal letters to many of the bishops. ${ }^{20}$ It is difficult to tell whether Leo's writings had any influence on the thoughts of the hierarchy except where they state so directly or are clearly aligning themselves with the Pope. However, it is clear that by 1891 the majority of the clergy and hierarchy in Ireland would have been well versed in Thomism, as Leo insisted from early on in his papacy that thorough studies of Aquinas be conducted as a regular course of

\footnotetext{
${ }^{18}$ Pope Leo XIII, 'Aeterni Patris: On the Restoration of Christian Philosophy', 4 August 1879, pt. 24.

${ }^{19}$ Joe Holland, Modern Catholic Social Teaching: The Popes Confront the Industrial Age (Mahwah, N.J.: Paulist Press, 2004), 122.

${ }^{20}$ These various groups of writings are all contained in the collections 'Segretaria di Stato: Spoglio di Leone XIII' and 'Segretaria di Stato: Moderne Parte', Archivio Segreto Vaticano (ASV) and at the Segretaria di Stato Sezione Per i Rapporti Con Gli Stati (SRRSS).
} 
study in seminaries throughout the world. ${ }^{21}$ Many of these concepts would therefore be familiar to the clergy by the time of Rerum Novarum's publication.

The Pope's view of Thomistic philosophy as the height of human wisdom led to an intransigence in his philosophical principles, if not Leo's politics. Though the Pope wrote without qualification in the first half of his papacy from 1878-1890, his negotiations with various political powers proved that his religious intransigence did not extend to temporal matters. In Prussia, for example, he worked against the wishes of Ludwig von Windthorst and the Catholic Centre Party by offering certain episcopal resignations to Otto von Bismarck in return for some educational autonomy for Catholics in Prussia. ${ }^{22}$ Yet even while these compromises were being made, Leo continued to write encyclicals which emphasised to politicians and the hierarchy certain Thomistic principles that were distinctly inflexible towards modern political debates. In Libertas (1888), for example, Leo argued that Christian liberty - that is, the right of Catholics to practice religion freely - was an inviolable human right in any just state which pursued the 'common end' of society (heaven). The Pope insisted that, unlike the modern liberal political system in which the unfettered moral liberty of the individual took precedence, a just political system was one in which 'all citizens work together for the attainment of the common end to the community' and that the state should ensure cooperation, 'forbidding them to depart from this end' through the 'injunctions of the civil law' so that 'all may more easily conform to the prescriptions of the eternal law'. ${ }^{23}$ Leo's argument here was carefully constructed to discard modern liberalism, and to maintain civil hierarchy and authority while restricting governments to one idea of the 'common end' as determined by eternal law and interpreted by the Church. Such arguments closely followed the concepts of the Thomistic state in maintaining the primacy of the Church in determining the final end of society with a rigidity which Leo consistently implemented throughout the majority of his papacy. Yet in 1891, the pope's approach changed entirely.

\section{Leo and the Land War}

\footnotetext{
${ }^{21}$ Patrick Justin O'Byrne, The Life and Pontificate of Leo XIII (New York: Charles L. Webster, 1903$), 32$.

${ }^{22}$ Margaret Lavinia Anderson, Windthorst: A Political Biography (Oxford: Clarendon Press, 1981), 323.

${ }^{23}$ Pope Leo XIII, 'Libertas: On the Nature of Human Liberty', 20 June 1888, pts. 9-10.
} 
In the reciprocal relationship between Rome and Ireland, the Pope's early encyclicals had inadvertently highlighted for the Irish hierarchy the Thomistic principles with which they could justify land agitation, while the same land agitation would later inform Rerum Novarum. The Land and National League's campaigns to reform the laws governing rent and their intent upon improving the situation of the tenantry caused controversy both in the Irish Church and in Rome. From the perspective of nationalist Archbishops, such as Cashel's Thomas Croke and Dublin's William J. Walsh, the Land War intended to restore justice in Irish society. ${ }^{24}$ Though they publicly decried any violent methods of protest and resistance, their defense of the Leagues and their cause was unflagging. Although the Land War was nominally an economic and legal struggle, it has long been seen by Irish historians as a political and cultural struggle as well. ${ }^{25}$ This second categorisation was very evident in the Irish Church during the 1880s, as the Land War divided the hierarchy between nationalists and ultramontanists. ${ }^{26}$

The contest between different emphases within the Church hierarchy did not contain itself to geographical borders, partly because of how sensational the Roman Curia found the Irish hierarchy's public disagreements with the Pope's opinions throughout the Land War. Various nationalist members of the Irish hierarchy flooded the Holy See with letters to convince Leo either that the Land War was not socialist in nature, that it was a licit cause, or that the violence with which the Leagues were often associated an outlier, rather than the norm amongst League members. Simultaneously, letters from anti-League or anti-Parnell bishops attempted to persuade the Holy See that the League's cause was inherently evil.

To argue their points, both factions utilized concepts derived from Thomism to discuss the legitimacy of a government, the delegitimation of authority, and the breakdown of the rule of law. From Dublin, for example, the nationalist Archbishop William J. Walsh defended the Land League against claims of communism by declaring: 'You are no Communists; the case lies quite

\footnotetext{
${ }^{24}$ Quotations from Croke and Walsh on this topic were extracted from Irish newspaper clippings and sent to Leo XIII in an anonymous letter. Unknown to Leo XIII, Propaganda Fide, Irlanda, Fondo 40, no. 353.

${ }^{25}$ See, for example, Paul Bew, Land and the National Question in Ireland (Dublin: Gill and Macmillan, 1978); Samuel Clark, Social Origins of the Irish Land War (Princeton University Press: 1979); James S. Donnelly Jr., The Land and the People of Ireland (London, 1975); Donnacha Seán Lucey, 'Power, politics and power relief during the Irish Land War, 1879-1882', Irish Historical Studies 37, no. 148 (November 2011): 584-598; Anne Kane, “'The Fall of Feudalism in Ireland": A Guide for Cultural Analysis of the Irish Land War', New Hibernia Review/Irish Éireannach Nua 15, no. 1 (Spring, 2001): 136-141.

${ }^{26}$ For more on ultramontanism in the Irish Church from the mid-nineteenth century, see Colin Barr, "'Imperium in Imperio"': Irish Episcopal Imperialism in the Nineteenth Century', The English Historical Review 123, no. 502 (2008): 611-650.
} 
the other way. It is you that are struggling against that which is little better than Communism. You are striving might and main to save your little lot from the usurpation and confiscation of those who would wrest it from you. Thus you are standing well within the lines of justice., 27 Walsh's words here serve three purposes: highlighting a right to own property derived from Aquinas and which would feature later in Rerum Novarum; usurpation and confiscation by the law as against personal rights and therefore illegitimate uses of power; and the justice in defending one's natural rights against an illegitimate rule of law. The anti-Land League bishops on the other hand usually pointed to the legitimacy of British governance, and the Thomistic principle that a good end cannot be attained by immoral means. The then Archbishop Edward MacCabe of Dublin, for example, wrote a pastoral letter in 1882 that praised Queen Victoria public and political works as constitutional and laudable, while he insisted her authority was legitimate because it was. 'gross violation of Christian duty to raise the hand of insult against the holder of God's authority. The hand that wields the sceptre might be soiled, but the sceptre was God's. ${ }^{28}$ He denounced the Land League's 'methods' by question 'How could God bless a cause, though good in itself, which was sustained by such unholy agencies? ${ }^{29}$ Walsh's comments supporting the Land League's methods as just, and MacCabe's impassioned pleas and descriptions of Land League agitations as violent and illegitimate are typical of the discursive divide between the pro- and anti-Land League Irish bishops and their letters to the Holy See.

Though the ongoing internal struggle to win the favor of the Holy See continued throughout the 1880s, there are certain major episodes of the Land War which stand out as both the most well-known, and the most formative. The first of these occurred in 1883, when the Pope responded to the creation of the Parnell Testimonial Fund by issuing a circolare banning Irish priests from participating in politics. Such a move was deemed necessary in Rome because correspondence had repeatedly arrived in the Propaganda Fide or the offices of the Holy See, from both hierarchical and lay sources, which described increasing Catholic participation in violent affairs over land agitations. ${ }^{30}$ The Fund in particular provoked a reaction from Rome

\footnotetext{
${ }^{27}$ From unmarked paper clippings sent to Leo XIII. Unknown to Leo XIII, Irlanda, Archivio di la Sacra Congregatione De Propaganda Fide (PF), Fondo 40, N. 353. See also Thomas Aquinas, Summa Theologica, 2.2. q. 66 , art. 2 ad 1. For a discussion on why the right to property is not a natural right but is an adinventio of positive law to natural law, see Anton Herman Chroust and Robert J. Affeldt, 'The Problem of Private Property According to Thomas Aquinas' Marquette Law Review, 34, No. 3 (Winter 1950-51), 151.

${ }^{28}$ Dr. McCabe on the Irish Outrages, Birmingham Daily Post, 13 March 1882, 8.

${ }^{29} \mathrm{Ibid}$.

${ }^{30}$ See for example, Irlanda, Fondo 40, N. 39: Scritti Riferite nei Congressi Irlanda, 1883, $P F$.
} 
because it was deemed to support a socialist leader. Such support, the Vatican feared, would only encourage the laity to participate in a political movement which Leo believed as operating against the legitimate rule of law and which encouraged common thievery of privately-owned land. ${ }^{31}$

The Pope's letter against clerical involvement in politics asserted that it was the duty of the Irish clergy to stop Catholics from 'rebellion against just laws' and the usurpation of justice by morally despicable means. ${ }^{32}$ Unsurprisingly, the demand that priests refrain from politics was not well received by the nationalist hierarchy. Croke in particular was very vocal about his disagreement, publicly denying that the circolare had any real implications for Irish priests. He claimed that Leo was misinformed about the situation in Ireland, and that the authority of the circolare was thereby negated, as it sought to address a situation which did not exist. Croke employed some of Leo's favorite principles about legality to emphasize his point, stating that the Irish bishops were "still the judges of what is "legal" or "lawful" or "illegal" or "unlawful" in the Irish agitation', and that by his estimation the Fund was a lawful endeavor. ${ }^{33} \mathrm{He}$ further argued that the Fund was a simple act of charity, and that therefore the Church should actually be encouraging donations to support Parnell. By using such language, Croke hoped to undermine the Pope's belief that the League was working against the rule of law but rather had Christian principles at its core.

Croke's implicit denial of the authority of the Pope earned him a curt summons to Rome, where he was asked to account for his continued support of the Testimonial Fund, clerical involvement in politics, and his defence of the League. Croke considered this visit to be a success, or at least boasted in letters and to the press that he had completely changed Leo's mind about the National League and land agitation more generally. ${ }^{34}$ The Propaganda Fide and Lord Errington (then the English diplomat to Italy) on the other hand, disagreed with Croke entirely. Errington wrote that the Pope had left Croke hanging around for days before receiving him with

\footnotetext{
${ }^{31}$ Although it was Davitt rather than Parnell who promoted socialist principles in the National League, the Vatican considered Parnell to be the ultimate leader and therefore blamed him for everything. Davitt's name only appears in two letters in the Secretary of State's Ireland collections in the ASV which discuss Davitt; in one of them, Manning declares that Parnell has quashed Davitt's socialist dreams for the Land League. Henry Manning to Leo XIII, 19 April 1884, Archivio Segreto Vaticano (ASV), Segretario di Stato, Spoglio di Leone XIII, Corrispondenzie del Card. Manning con Leone XIII circa questioni Irlandesi e altri documenti circa Irlanda, busta 82, fasc. 366.

${ }^{32}$ Letter of the Sacra Congregatione De Propaganda Fide to the Bishops of Ireland, PF, Irlanda, N. 552, 11 May 1883.

33 'The Pope's Circular,' Freeman's Journal, 19 May 1883, 5.

34 'Archbishop Croke and the Pope', Bristol Mercury, 22 May 1883, 8.
} 
hostility, while the minutes of the Propaganda Fide noted that coldness and brevity best described the Pope's attitude. ${ }^{35}$ Such an account of Croke's time in Rome seem more likely than the Archbishop's version, as the Pope's injunction against clerical involvement in politics was not lifted. Despite this, Croke continued to insist that he had convinced the Pope of the legitimacy of the League's claims.

Croke's perceived victory, however, was short-lived. In 1885, after the drought of the autumn of 1884 had caused significant strain on the Irish peasantry, the bishops of Ireland once again acted against the express wishes of the Pope. For his part, Croke openly endorsed nationalist candidates for election, and allowed the priests in his diocese to take active roles in generating support for nationalist politicians. ${ }^{36}$ Similar situations were reported to the Holy See about the dioceses in Cork and Clonfert, while in Tuam Archbishop John MacEvilly suspended the Peter's Pence collection (a monthly collection for the maintenance of the Vatican), so that the tenantry would be better able to pay rents until the landlords granted lower rental rates. ${ }^{37}$ In Dublin, Archbishop William J. Walsh contributed money to the National League to support tenants in crisis. ${ }^{38}$ Though both MacEvilly and Walsh echoed Croke's 1883 defense by claiming that their actions were inspired by charity, their behaviour signaled to Rome that there was a severe loss of papal authority in Ireland as they had again openly disobeyed the 1883 circolare.

The disagreements between Rome and the Irish hierarchy were important to the development of the Catholic lay political imagination because of the publicity with which they were conducted. Though during the 1880 s not many of the agrarian or working-class laity in Ireland would have conceived their struggles as a dismissal of the rule of law or a delegitimizing of authority, such concepts were very much a part of their public sphere. Newspaper articles about the Church's politics, pastoral letters read out to Sunday congregations and published in periodicals, and other public speeches by the hierarchy were all in common circulation during the Land War. Croke, for example, was reported in 1884 as having spoken spontaneously to a crowd in Kildare, stating 'We are waging a constitutional fight for its [Ireland's] advancement

\footnotetext{
${ }^{35}$ Mark Tierney, Croke of Cashel: The Life of Archbishop Tomas William Croke 1823-1902 (Dublin: Gill and Macmillan, 1976), 148-149.

${ }^{36}$ Ibid., 152-171.

${ }^{37}$ Macaulay, The Holy See, 23.

38 Ibid.
} 
and social emancipation; and I am sure I can safely say of you, as I do of myself, that we shall never lay down our arms in this laudable and legitimate combat'. ${ }^{39}$

To many Irish nationalists, Croke was the man who taught them to 'how to reconcile the two most passionate cravings of their hearts: the spiritual longings and the national aspirations., 40 The contributions of other members of the hierarchy to the nationalist cause were not forgotten either, as Walsh too was praised as the 'patriotic prelate' in Dublin, and his efforts in securing financial contributions from the diasporas were praised regularly by the newspapers. ${ }^{41}$ Like Croke, Walsh also publicly jumped to the defense of the League, directly contradicting Leo's statements about the communistic or socialist nature of the land agitation. In a public speech which was later sent to Leo, Walsh stated: 'You are no Communists; the case lies quite the other way [...] you are standing well within the lines of justice. ${ }^{42}$ In both speeches by the archbishops, the language used reflected both Leo's writings and his antecedent, Aquinas, in emphasizing the necessity for and the right to seek justice in society by legitimate means. Such rhetoric was striking to the Pope, because it was exactly a lack of justice and illegitimate methods of protest which Leo associated with the National League and land agitation.

The use of the Pope's language for the opposite purpose than that which Leo intended in Ireland was troubling to the Vatican, further signaling a decline in papal authority and control, and was read as a decrease in principled Catholic action in Ireland. Towards the end of 1886, the Plan of Campaign, an organized series of rent strikes co-ordinated by the Irish National League, spurred the Holy See into action against the nationalists within the Irish Church. Though similar to what had been occurring in Ireland for most of the 1880s, the Plan of Campaign differed from the League's prior land agitation by collecting withheld rent to financially support evicted tenants. ${ }^{43}$ Despite much of the Irish Church lauding the Plan of Campaign as charitable, the Holy See denounced the Plan as thievery, as the Vatican considered helping the tenants who had withheld rent and were then evicted as complicity in the original theft.

\footnotetext{
39 'Archbishop Croke in Kildare: The Patriot Prelate Meets with an Enthusiastic Reception', Leinster Leader, 20 Saturday $1884,3$.

40 'The Moral of the Archbishop's Welcome Home', Flag of Ireland, 13 June 1885, 5.

41 'Clondalkin National League', Freeman's Journal, 14 September 1885, 6; 'Archbishop Walsh and the National League', St. James's Gazette, 15 October 1886, 8.

${ }^{42}$ Unknown to Pope Leo XIII, $P F$, Irlanda, Fondo 40, No. 353.

${ }^{43}$ F.S.L. Lyons, 'John Dillon and the Plan of Campaign, 1886-90', Irish Historical Studies 14, no. 56 (Sept. 1965 ): 318-319.
} 
The bishop of Ross, John Power, contributed to this view by sending newspaper clippings to the Holy See which told of the use of boycotting, describing it as drastically and negatively effecting businesses who had relationship to the affairs of land agitation or rent. ${ }^{44}$ Another newspaper clipping which Power sent reported that 'at meetings language advising open resistance to the law [boycotting] has been frequently used' in support of the Campaign. ${ }^{45}$ Other bishops compounded Roman fears of the Plan of Campaign and boycotting by their letters to the Vatican explaining that they had trouble controlling lay and clerical involvement in the Campaign because of statements of support by other bishops, particularly Croke. While the bishops of Ossory, Galway, and Dublin each joined in supporting the National League publicly, it was Croke who pronounced that the National League was becoming a great success all while 'working within constitutional lines'. ${ }^{46}$ Whether or not this was true, the Vatican viewed the National League as resisting a legitimate authority in the British state.

The legitimacy of the British government was particularly important to Leo's condemnation of the Plan of Campaign and boycotting. The Coercion Act of 1887, for example, criminalized boycotting, unlawful, assembly, conspiracy against paying rent and intimidation and abolished trial by jury and was publicly denounced as an egregious overstep of governmental authority by the nationalists of the Irish Church. Nevertheless, the Act and the British Government were upheld as lawful and legitimate by the Holy See. ${ }^{47}$ As the Coercion Act was passed by what Leo accepted as a legitimate authority and it was designed to prevent boycotting, unlawful assembly, conspiracy against paying rent and intimidation, the Pope found no reason to denounce the Act and many reasons to support it. Croke was enraged by both the Coercion Act and Rome's silence, and thus wrote his 'No Rent Manifesto' insisting that the Irish should not pay 'taxes to a Government that uses them, not for the public good and in accordance with the declared wishes of the taxpayers, but in direct and deliberate opposition to them'. ${ }^{48}$ In this manifesto, Croke was echoing Thomistic principles about the legitimacy of a government which

\footnotetext{
44 John Power to Giovanni Cardinal Simeoni, Propaganda Fide, Irlanda, Fondo 42: 1886-1887, no. 91.

45 Ibid.

46 'Archbishop Croke on the National League [in Lismore]', St. James's Gazette, 8 March 1886, 12; 'The Archbishop of Cashel [in Dungarvon]', Weekly Irish Times, 13 March 1886, 5; 'Lenten Pastorals', Weekly Irish Times, 13 March 1886, 5.

${ }^{47}$ Pope Leo XIII to Ireland, ASV, Spoglio di Leone XIII: Segretaria di Stato, busta 82, fascicolo 366. 48 'Archbishop Croke - No Tax. Scandalous Advice. Warning from Government.' Belfast News-Letter, 1 March 1887,8 .
} 
disregarded the common good to claim that the British government had delegitimized itself by acting against the greater good and will of the people.

The Archbishop's manifesto and the principles it used to justify otherwise immoral public action provoked a frenzied response from the Pope. ${ }^{49}$ Croke and Walsh attempted to head this response off by writing to Propaganda and the Irish College in Rome to justify the Manifesto. ${ }^{50}$ All three letters to Rome appear to have been written in a hurry, and argue that the government was responsible for the crisis by illegally suspending trials by jury, and had thus delegitimized itself by refusing to uphold a just law. ${ }^{51}$ The argument simply did not convince Leo because a movement that espoused or resulted in violence was illegitimate in his view. There was no question in Leo's mind that the government was not responsible for the unrest in Ireland, but that the blame lay with the National League, the Plan of Campaign, and wildly errant bishops who promoted movements which espoused violence and socialistic resistance.

By the end of 1887, the Holy See had no clear view of the Irish situation and assigned an apostolic delegate, Archbishop Ignazio Persico, to investigate. The conclusions of this report on the National League and the Plan of Campaign confirmed the fears of the Holy See. Persico emphasized that the League's meetings 'prepared the incendiary addresses which did great harm to the people and subverted public order' and that the Plan of Campaign was 'an extreme measure. ${ }^{52}$ The Italian archbishop also observed that with few exceptions, bishops and clergy were involved in League agitations; any statements against the League by other bishops were largely ignored by priests and people alike. ${ }^{53}$ Persico's most damning criticism of Parnell, the League and the Plan of Campaign, however, was that they were a 'gubernium in gubernio' - a shadow state which sought to replace the British state with an Irish nation that governed the people through the collections of rent and the intimidation of boycotting. ${ }^{54}$

This last critique would have been most concerning to Leo as both an usurpation of state authority and for its potential to result in a new state in Ireland which espoused what he viewed

\footnotetext{
${ }^{49}$ Pope Leo XIII to Ireland, ASV, b. 82, fasc. 366.

${ }^{50}$ Croke and Walsh to Leo XIII, 1887, PF, Irlanda, Fondo 42: 1886-1887, no. 452; William J. Walsh to Tobias Kirby, Rector of the Irish College, 9 March 1887, Pontificio Collegio Irlandese, KIR/1887/139.

${ }^{51}$ Croke and Walsh to Leo XIII, $P F$, Fondo 42, no. 452.

${ }^{52}$ Persico's Report to the Vatican Secretary of State, Cardinal Mariano Rampolla del Tindaro, as quoted in Macauley, The Holy See, 119. It should be noted that at the time of research for this project, the relevant files for this topic were unavailable for reference in the archives.

${ }^{53}$ Alberto Belletti, 'Cattolicesimo e Nazionalismo nell'Irlanda di fine Ottocento: La Chiesa e il movimento di Charles Stewart Parnell', (Phd diss., Università di Pisa), 181.

${ }^{54}$ Ibid.
} 
as socialist principles, without any sort of governmental ties to the Church. Persico's conclusions were disastrous for the nationalist hierarchy, as they prompted the Supreme Congregation of the Holy Roman and Universal Inquisition to review the Irish situation and to determine if the Plan of Campaign and Boycotting were licit forms of resistance. and suggest a course of action. ${ }^{55}$ The result of this review was the drawing up of a Papal Decree condemning and banning participation in the League, the Plan of Campaign, and boycotting. ${ }^{56}$ The Decree, however, never made it to Leo's desk before its leak to the Irish press in April 1888. The leaked document caused widespread outcry against Roman interference in the Irish Church, including, for example, arguments that 'the Laity will be free to pursue their political ends in their own way' because the Decree was only addressed to the Roman Clergy in Ireland. ${ }^{57}$

For their part, the nationalist Irish bishops were incensed by the Decree, but they maintained publicly that as it was in technicality a papal rescript, it held no authority over the laity but only specifically banned clerical involvement. The argument used by the Irish hierarchy was similar to that which Croke employed in 1883 - the papal rescript was addressed only to the Irish bishops and was not a papal bull nor a motu proprio, which are addressed to the universal Church. Walsh argued moreover that rescripts only addressed one particular issue, and thus held only the force of a particular law - that is, it was only binding to those individual groups to whom it was addressed and loses its authority when a falsehood is attached to the information of initial concern.

Following this line, the Irish clergy sought to deny the authority of the Decree, either by denying the validity of papal authority in this situation, or by ignoring the Decree's four main points. Firstly, the Vatican had emphasized that it was unlawful to break a contract freely entered into (tenants' rents); secondly, there was already recourse for regulating unfair rents through the land courts and therefore there was no lawful reason for protest or resistance; thirdly, the money given to the Campaign had been collected largely by extortion, making it an immoral collection; and lastly, boycotting was contrary to justice and charity and was rejected as a legitimate method of protest as it was coercion against those tenants who wished to pay rent or other businesses who freely and justly entered into commerce with landlords. Rather than

\footnotetext{
55 Ibid., 182.

56 Pope Leo XIII, 'Saepe Nos: On Boycotting in Ireland', 24 June 1888, trans. Claudia Carlen, The Papal Encyclicals, 1878-1903 (Raleigh, N.C.: McGrath Publishing Company, 1981).

${ }^{57}$ Untitled, The Western Times, 20 April 1888, 2.
} 
grappling with the issues laid out in the Decree, Croke maintained that the Pope was misinformed by falsehoods because the Plan of Campaign did not intimidate tenants, and that the courts were unjust, and therefore the rescript did not hold its legality within canon law. ${ }^{58}$ Walsh argued from Dublin that the rescript was invalid because it considered the Plan of Campaign as 'a new form of warfare', was deemed illicit by the Holy See; but, he argued, Ireland was not in fact at war with England at all (despite his earlier comments about legitimate combat). ${ }^{59}$ Such arguments may have assuaged some Irish anxiety as to whether they must obey the rescript, but they only served to further weaken the relationship between the Roman Curia and the Irish hierarchy.

In response to the nationalist hierarchy's denial of the authority of the Papal Rescript, Leo released a public encyclical to Ireland a few months later in June, under the title Saepe Nos: On Boycotting in Ireland. The encyclical confirmed the contents of the rescript, proscribing 'those methods of warfare known as Boycotting and the Plan of Campaign' as morally illicit. ${ }^{60}$ The encyclical made it clear that Ireland had earned the Pope's ire for having 'the real scope of the Decree perverted by means of forced interpretations' and having 'denied that obedience is due to the Decree. ${ }^{61}$ To address the criticism that the Decree was an unnecessary Roman foray into politics, the Pope emphasized that it was the 'true and proper office of the Church to decide what is right and what is wrong in human actions' and that obedience to legitimate authority was central to Christianity. ${ }^{62}$ The Irish Church by and large, however, continued to participate in the National League.

Though the Irish situation would continue to deteriorate in the eyes of the Holy See after the publication of Saepe Nos, the Pope's debates with the Irish hierarchy over the legitimacy of the National League, the Plan of Campaign, and their methods were at an end. Croke and Walsh had often deployed bits of Thomistic principles and canon law to undermine papal authority and Leo's own philosophical reasoning. To do so publicly, as the archbishops had on many occasions, worsened what Leo considered the degradation of respect for legitimate authority both temporal and spiritual - across Catholic Ireland. When personal letters, meetings with the hierarchy, a papal delegate, a papal decree, and an encyclical had all failed to impose upon the

\footnotetext{
${ }^{58}$ Patrick J. Walsh, William J. Walsh: Archbishop of Dublin (Dublin: The Talbot Press, 1928), 338.

${ }^{59}$ Ibid.

${ }^{60}$ Pope Leo XIII, Saepe Nos, 24 June 1888, pt. 2.

${ }^{61} \mathrm{Ibid}$.

${ }^{62}$ Ibid.
} 
Irish Church the understanding of the respect due to a legitimate state, the Holy See found it necessary to find a new method of influencing and controlling the laity.

\section{Rerum Novarum and the People}

The use of Thomistic principles to defend illegitimate methods of protest and resistance particularly bothered Leo, as he held a specific view of Aquinas's thought. To his mind, the nationalist Irish hierarchy had publicly misused or misinterpreted Thomistic principles in their defense of the National League, as Leo noted in Saepe Nos. Without being able to rely on the hierarchy to properly instruct the laity in their duties as 'Christian citizens' in obeying a legitimate state, the Pope turned to the laity directly. ${ }^{63}$ To do so, Leo released his masterwork, the encyclical De Rerum Novarum: On Capital and Labour in $1891 .^{64}$ Though nominally addressing economic and social issues, what the Pope presented in this encyclical was a scheme of civil society which sought to answer the questions posed by socialism about the duties of the wealthy and of the state to care for the lower classes. Leo's ideal civil society was founded upon the Thomistic concepts of the relationships between the state authority, the common good, and the people, as addressed in the first section of this article.

Unlike previous encyclicals which were meant either for the hierarchy alone or to be read out and explained during Sunday Masses, Rerum Novarum was addressed to the laity directly, used emotive language, and its publication was widespread. ${ }^{65}$ This would have a profound impact on how the laity were able to engage with and appropriate the Thomistic principles Leo had used to address modern issues, such as the lure of socialism and the use of morally illicit methods of protest and resistance. The form in which these issues were presented in the encyclical was only partially explained and often left some ambiguity as to what Leo actually intended. Without the interpretation or guidance of the clergy, many of the Thomistic principles in Rerum Novarum held only a ring of familiarity for the laity, but no proper meaning beyond that which they wished to assign.

\footnotetext{
${ }^{63}$ Leo addresses the proper role of Christian citizens and their duties within a legitimate state in his 1885 encyclical, Immortale Dei, and again in an 1890 encyclical, 'Sapientiae Christianae: On Christians as Citizens', 10 January 1890.

${ }^{64}$ Pope Leo XIII, 'De Rerum Novarum: On Capital and Labour', 15 May 1891.

65 This process is fully analyzed and traced in Luminiello, Confronting Modernity, 175-185.
} 
In Rerum Novarum, Leo reasserted that that a natural hierarchy was to be followed in society. In doing so, the Pope also made clear that he also expected that the hierarchy of law was to be respected, and divine law privileged over human law. ${ }^{66}$ Thus, when the demands of the state competed with the moral demands of the Church, as Leo had previously argued, the Church must be obeyed over the state. ${ }^{67}$ In Rerum Novarum this particular duty is not explicitly articulated, but is rather assumed in brief points about the individual preceding the duties of the State in the simple phrase: 'Man precedes the State' ${ }^{68}$ The state was further tasked in Rerum Novarum with protecting the common good and the rights of the people. Though this was meant to refer to protecting the rights of private property against socialism, the Pope simply wrote that 'rights must always be religiously respected wherever they exist [...] it is the duty of authority to prevent and to punish injury' against these rights. ${ }^{69}$

Which specific rights Leo was referring to was not immediately clear, but for the casual reader and taken as a whole the section the section seems to clarify that what he meant was the right to the free practice of religion. He goes on, for example, to task the state with protecting the interests of the worker, most especially the interests of the soul, including making sure that employers provided for Sunday rest. ${ }^{70}$ To fail to provide for or to protect the free practice of religion would be contrary to what was 'right and just' in society. ${ }^{71}$ Later in Rerum Novarum Leo also asserted that workers had a natural right (in the Thomistic sense) to associate in what he termed 'private societies' (after the style of Aquinas). This right in particular he protected firmly against the state, emphasising that they could not be 'prohibited by public authority', as the state is meant to 'protect natural rights and not to destroy them'. ${ }^{72}$ The final two rights which would prove influential in Irish society were the rights to a fair pay for work freely entered into, as well

\footnotetext{
${ }^{66}$ Usually in studies of Thomism and other Catholic philosophical texts 'eternal law' and 'divine law' are used interchangeably, and often Aquinas himself is not always clear to which he is referring. Where he properly defines them, eternal law is 'Divine Wisdom': the creator from whence the ordering of creation is enacted (I.II, q. 93, a.1) and divine law is the articulation of eternal law to humanity (through scripture) to guide human and natural law towards attainment not simply of temporal ends, but of the ultimate end. When speaking of society, therefore, divine law is usually preferred and will be used throughout this article similarly, unless a distinction is otherwise necessary.

${ }^{67}$ Leo XIII, Sapientiae Christiane, pts. 5-7.

${ }^{68}$ Rerum Novarum, pt. 7.

${ }^{69}$ Ibid., pt 36.

${ }^{70}$ Ibid., pt. 40,

${ }^{71}$ Ibid., pt. 42.

${ }^{72}$ Ibid., pt. 51.
} 
as the right to safety in workplaces. ${ }^{73}$ Both rights, Leo argued, were to be protected first by the employer, and if the employer failed, by the state. As these rights were to be 'religiously respected wherever they exist', failure to uphold the rights of would constitute a 'great crime' which cries 'to the avenging anger of Heaven'. ${ }^{74}$

It was language such as this which would serve as a way to legitimize extrajudicial measures taken by groups who felt that the state had not protected their ability to freely practice Catholicism. Particularly in Ireland, two factors contributed significantly to the use of these sections of Rerum Novarum outside of their intended context. First, there was already an existing and familiar narrative, dating at least to the time of O'Connell and Catholic Emancipation, which viewed the true Irish nation as Catholic and the Protestant state as a usurper. This idea had been articulated repeatedly by politicians and clergy alike. In 1885, for example, Walsh delivered a speech at the opening of St. Patrick's Training College in Dublin in which he stated that 'the attempt to force upon the people of this Catholic nation a system which, if it were equally opposed to the feelings of the Protestant people of England, the strongest Minister of our day would not have the hardihood to attempt to force upon them, or if he had the hardihood to make the attempt, could do so only with the result of very soon making the discovery that the days of his ministry were ended. ${ }^{, 75} \mathrm{He}$ followed this by saying that the grant given to the training college by the government was so small that it was 'unjust.'

The ideas embedded in this section of the Archbishop's speech are tropes with which Irish historians are very familiar, as the rhetoric used was commonplace during the 1880s, both in public speech and in the newspapers. Yet when they are looked at in the context of the Thomistic discourse through which Leo communicated, Walsh's argument that Ireland, as an inherently Catholic nation, was unjustly oppressed against the common good of the people by the Protestant state's restriction of religious rights (in this case, the right to provide education), corresponded with the Pope's critique. Though the Irish laity may not have been able to put it in these words, seeing the Thomistic ideas in their own form would have had a familiarity to them when contextualised by their own situation. In 1887, for example, Croke told reporters that he would have supported a movement 'against the payment of taxes to Government, which used

\footnotetext{
73 Ibid., pt. 45.

${ }^{74}$ Ibid., pt. 37; idem, pt. 20.

75 'Visit of the Archbishop of Dublin to St. Patrick's Training College', Freeman's Journal, 30 September $1885,5$.
} 
them in direct opposition to the wishes of the taxpayers. ${ }^{76}$ Though not explicitly stated by Croke, this was an application of the Thomistic principle of the common good and legitimate governance. The logic behind his statement was that the numerical majority of Irish citizens who nominally payed taxes were opposed to the British government's use of those funds, and thus the government was working against the common good. In Rerum Novarum, the same principle was articulated to describe the legitimacy and duties of the state twice; in the first instance, Leo explicitly stated that 'it is the province of the commonwealth to serve the common good' and urged that more was to be 'done for the benefit of the working classes by the general laws of the country. ${ }^{, 77}$ Later in the encyclical, he stated 'Civil society exists for the common good'. ${ }^{78}$ Leo's statement of these philosophical principles were simply articulating the Thomistic logic behind statements such as Croke's, making explicit the justifications used by the nationalist Irish bishops during the 1880s. Here and in other places, Rerum Novarum implicitly and unintentionally presented a philosophical logic behind the rhetoric used by nationalists and the nationalist clergy to justify certain political stances during the 1880 s.

Although the Holy See did not seem to be aware of any unusual reactions to Rerum Novarum immediately after its publication, it became clear that something had gone wrong with the Pope's appeal to the people. Five years after Rerum Novarum had been released, Eduardo Soderini prepared to publish a short book, Socialism and Catholicism, which sought to clarify the Church's position on socialism, strikes, and workers' associations. ${ }^{79}$ With Leo's consent, the volume was written as a further exploration of what he had proposed in Rerum Novarum, and was deemed necessary because in Soderini's words, 'the instructions of the Papal encyclicals and the mission of the Catholic Church [...] adapting herself to the new times, have been misunderstood, different and wrong interpretations' had been made, and a 'setting forth of the real view of the Pontiff' was in order. ${ }^{80}$ Particularly in Ireland, where Catholics made up the numerical majority but were otherwise faced with social, economic, or state oppression, the rights, duties and exhortations in Rerum Novarum affected considerably how Catholic communities and associations perceived their role in society, particularly through the

\footnotetext{
76 'Archbishop Croke and the Agitators,' Bucks Herald, 19 February 1887, 8.

${ }^{77}$ Leo XIII, Rerum Novarum, pt. 32.

${ }^{78}$ Ibid., pt. 51.

${ }^{79}$ Eduardo Soderini, trans. by Le Monnier, Socialisme et Catholicisme (Société de Saint-Augustin, Desclée : De Brouwer et Co., 1896).

80 'Socialism and Catholicism. Views of the Pope on Their Relation.', 20 Feb. 1896, Pall Mall Gazette, Vol. 62, No. 9643, 9 .
} 
presentation of the encyclical by the popular press. The result was an increasing tendency of Catholics to determine the public morality of their actions using principles found in Rerum Novarum as legitimation.

Key to this process was the popular press and its presentation of the encyclical. After its initial release in 1891, Rerum Novarum was translated into the vernacular, published both in whole and in parts, quoted and interpreted by the popular press, and used to justify positions contrary to Leo's intent. The nationalist Freeman's Journal, for example, wrote that the state's function was to promote tranquility and the 'common welfare', emphasizing that if the state refused to intervene on behalf of the 'corporal or the spiritual' welfare of citizens, it would be 'completely wanting in its mission'. 81 Though the Pope in Rerum Novarum had specifically limited the role of the state in intervening in social affairs and determining the common good, the Freeman's Journal also interpreted such sections to mean that 'it is contestable, he [Leo] holds, that, speaking in a general fashion, the State should always cooperate in the advancement of the working classes'.82 Other newspapers, such as the conservative Irish Times, simply published the encyclical in full and without commentary, allowing its readers to make of the Pope's words what they would. ${ }^{83}$

Because of the central importance in Ireland of religious identity in determining belonging in the political community - usually conceived as the Irish nation - Rerum Novarum's concepts of the right to the free practice of religion would be central to legitimization strategies. As the encyclical was primarily designed to answer economic questions and provide an alternative to socialism, the working classes latched onto the Pope's words to justify sectarian incidences in the workplace. This was especially true in Ulster, where the majority of businesses were owned by Protestants, and tensions between Catholic and Protestant workers had become normalized.

Such a state of affairs lent itself to situations where the Catholic laity needed to legitimize any aggressive actions they might take. Prior to the release of Rerum Novarum, the Irish hierarchy was fairly successful at keeping the laity out of socialist or workers' movements, despite what the Vatican thought about the National League. After 1891, however, the newspaper accounts of unrest or agitations caused by Catholic trade and workers' unions and

\footnotetext{
81 'The Pope's Great Encyclical,' 21 May 1891, Freeman's Journal, Vol. 125, 5.

${ }^{82}$ Ibid.

83 'The Pope's Encyclical,' Irish Times, 8 June 1891, Vol. 33, No. 10,386, 6.
} 
associations began to appear more frequently. In the 1890s, as organised Labour was beginning to find its feet in Ireland and workers' agitations were on the rise, the fears of the hierarchy and clergy in Ulster were becoming increasingly realized. In urban centres particularly, where the Church struggled to maintain social control, the reception of the encyclical became a major concern as the laity became increasingly involved in sectarianism, ethnic conflict, and violence in the workplace. Emmet Larkin has described the encyclical as having 'posed more problems than it solved', because Leo had agreed with many of the concerns of the socialists, condemned their methods and unions, and yet offered no alternative beyond encouraging the laity to start their own movements. ${ }^{84}$

In Ulster a hard line cannot be drawn between incidences which were purely sectarian, political, or those which had an underlining economic cause. In any case, the legitimation of such incidences was similar and often revolved around the right to disobey an unjust law or the right to practice religion freely. There were often, for example, local prohibitions against Catholics passing through geographical boundaries around Protestant neighborhoods and towns, or vice versa, in order to protect both parties from sectarian outrages. Yet often, Catholics would disobey such prohibitions, claiming the rule to be illegitimate, as they had the right to go where they pleased and therefore they did not have to obey the injunction. One such case was brought before the Antrim Assizes in 1897, when a Catholic band from the Greencastle neighborhood in Belfast entered Whitehouse accompanied by the police, and despite the ban, began throwing stones at a pub and assaulting the policemen there. ${ }^{85}$ The band maintained afterwards that they had a 'right to associate', using an argument similar to that in Rerum Novarum in which Leo maintained that 'All such societies [unions and organisations], being free to exist, have the further right to adopt such rules and organization as may best conduce to the attainment of their respective objects'. ${ }^{86}$ Some of the accused further insisted that the police had instigated the riot by stopping them in their travels - they were, they maintained, merely defending themselves against an unjust use of the law. ${ }^{87}$

A similar incident took place in Ballygawley, County Tyrone in 1900, when a Catholic nationalist band moved through the town, approached the Orange Hall, and sang O'Donnell Abú,

\footnotetext{
${ }^{84}$ Leo XIII, Rerum Novarum, pts. 49, 39, 20.

${ }^{85}$ Belfast Crown Book at Quarter Assize 1890-1902, Public Records Office of Northern Ireland [hereafter cited as PRONI], ANT1/A/7.

${ }^{86}$ Ibid; Leo XIII, Rerum Novarum, pt. 56.

${ }^{87}$ PRONI, ANT1/A/7; 'The Recent Disturbances in Greencastle,' Belfast News-Letter, 14 May 1897, 6.
} 
about the Catholic defeat of Protestants in the seventeenth century. This incited the Protestants present to jeer at them, and ultimately resulted in a physical altercation between the two parties. The Catholics who instigated the incident made similar claims to the those of the Greencastle band: they done nothing wrong, as they were simply exercising their right to associate when they were attacked. ${ }^{8}$ Such incidents were not isolated, nor was the excuse unusual. The right to associate which had been championed by the Pope quickly became a favorite justification of rioting in Ulster.

The effects of continued sectarianism throughout Ulster - regardless of its initial reason significantly impacted upon the working conditions and pay of Catholic workers throughout the province. Sectarianism was inescapable for the working class, particularly in their places of work. ${ }^{89}$ In 1899 , for example, when Orange feeling was still running high from the previous year's centenary celebration of the 1798 United Irishmen Rebellion, Catholic workers were targeted at their workplaces. One young woman, for example, working in a weaving factory on Agnes Street in Belfast, was harassed by Protestant workers there who hung rosary beads in the 'main pass' of the factory to mock her religious identity; within the factory grounds, she was 'spat at by the Protestant workers. Orange and blue ribbon was placed on her loom, and all the stove pipes in the establishment were decorated with the same colours' to mock her for her confessional identity. ${ }^{90}$

The effect of such sectarian episodes served as a basis for Catholics to claim that their right to have a safe working environment - as they had been told in Rerum Novarum - should be protected by the state, and that this was not being done. Workplace aggression or violence against Catholics was a good excuse to legitimize violence by claiming that their rights to safety in the workplace had not been protected. Often, Catholic workers viewed themselves as having the right to self-protection either as individuals or as a community when attacked for their religion, and when their employer or the state would not protect them. In such cases, many Catholics even viewed themselves as the legitimate arbiters of justice where the state had failed to uphold true justice. ${ }^{91}$

\footnotetext{
${ }^{88}$ Deposition of Queen by Rolston PJ v. Campbell, Grimes, Davison, and Hanna, 1900, PRONI, TYR/1/2/B/1/9.

${ }^{89}$ Sean Farrell, Rituals and Riots: Sectarian Violence and Political Culture in Ulster, 1784-1886 (Lexington: University of Kentucky Press, 2009), 135.

90 'Savage Treatment of Catholic Workers', Irish News and Belfast Morning News 8 June 1899, 5.

${ }^{91}$ Carolyn A. Conley, 'No Pedestals: Women and Violence in Late Nineteenth-Century Ireland', Journal of Social History, 28, no. 4 (Summer, 1995): 802-803.
} 
In light of such perception of the right of Catholics to pursue justice when the safety of their workplace had been compromised, the 1899 incident in the linen factory and others like it illustrate how conflict in the workplace offered a reason for Catholic workers to strike or to protest against employers. As in the case of the Agnes Street factory girl, Protestant employers often disregarded sectarian harassment and punished Catholic workers for not being productive, despite hostile circumstances. In other cases, Protestant employers failed in the duties assigned to them in Rerum Novarum by tolerating the sectarianism against Catholics. In 1893, for example, notices appeared around Belfast that no Home Rulers would be allowed to work into Harland and Wolff's shipyards; though these were not posted by the company itself, when the Catholic workers arrived on the Monday morning, they found the gates barred against them. Riots ensued, several Catholics were beaten, a Catholic public-house was destroyed that night, and Catholics set watchfires in their neighborhoods to protect themselves from further attacks because the police had failed to protect them. ${ }^{92}$

This followed the logic in Rerum Novarum, wherein the Pope had explained that if an employer failed to provide a safe workplace and the state failed to protect the community, the community was entitled to protect itself. Though such arguments were not clearly articulated by riotous Catholic workers, they had been repeated to them through the newspapers and through the wide publication of Rerum Novarum. The Belfast Weekly News, for example, promoted the idea that the pope's encyclical 'lays down' that the state must 'do its part in benefitting the working classes,' and in particular that it 'maintains that the State can and ought to intervene whenever it has to fulfil its duty of protecting the common welfare'. ${ }^{93}$ The newspapers were key to the misunderstanding surrounding the encyclical, as they often only published certain extracts in Ireland. Archbishop Walsh, for example, provided the Dublin Daily Express with a translation of the encyclical, yet the newspaper only published the sections which related to the rights of workers to associate under the state's protection. ${ }^{94}$ Other newspapers across Ireland similarly distorted the intent of the encyclical. The Belfast News-Letter, for example, solely highlighted in its first article on the encyclical that 'Papal these is in favour of State intervention as the only available method of regulating the movement [socialism],' whereas the Belfast Weekly News and the Mid-Ulster Mail insisted that the Pope was only in favour of state intervention when

\footnotetext{
92 'Ruffianism and Riot in Belfast. A War Against Catholics', Dublin Evening Telegraph, 24 April 1893, 3.

93 'The Pope's Encyclical', Belfast Weekly News, (23 May 1891), 3.

94 'The Pope's Encyclical,' Dublin Daily Express, (1 June 1891), 5-6.
} 
'necessarily applicable in an absolute and uniform manner' and with variances 'according to the needs and character of each nation. ${ }^{95}$ Such articles provided the Catholic laity with excuses to conduct various forms of protest and resistance, casting them in the light of their rights against a state which had delegitimized its own authority by failing to protect them or passing unjust laws, or as self-defensive actions because the state and employers had failed them.

The ways in which traditional Catholic philosophy and moral theology affected how Irish Catholics viewed their rights within the political community and their relationship with the state are varied and vast. Many of the Thomistic principles of legitimate state authority and its duty to citizens can be traced through modern Irish history, especially in the writings and speeches of the Irish hierarchy throughout the nineteenth century. ${ }^{96}$ The particular contribution of Leo XIII and Rerum Novarum was to bring the ideas of Aquinas directly to the lower-class laity. The publication of the encyclical enabled the laity to legitimize their own protest and resistance to the state, giving them a sense of moral authority for which they had previously to rely on the discourses of the middle and upper-class politicians and churchmen. Though to an extent the Thomistic understanding of the civil society and the state had always underpinned Irish political thought, Rerum Novarum fundamentally shifted how Irish Catholics staged morally illicit protest and resistance and yet maintained their identity as Catholic citizens. When Michael Davitt had boldly stated 'Ireland is not going to take her orders from Rome!', he had not counted on the unwitting assistance of Pope Leo XIII. ${ }^{97}$

\footnotetext{
95 'The Pope on Socialism', Belfast News-Letter, (8 May 1891), 6; 'Papal Encyclical', Belfast Weekly News, (16 May 1891), 3; 'Papal Encyclical', Mid-Ulster Mail, (16 May 1891), 4.

${ }^{96} \mathrm{See}$, for example, Croke's denial of the legitimacy of British governance in Ireland through their neglect of 'justice' and on how the 'British constitution has been practically cancelled' by unjust imprisonments: 'The Archbishop of Cashel, Dublin Weekly Nation, (12 November 1881), 2. Many other examples can be found in Patrick J. Walsh, William J. Walsh, Archbishop of Dublin (Dublin: Talbot Press, 1928).

97 'Mr. Michael Davitt on the Papal Circular', Freeman's Journal, 20 April 1888, 5.
} 


\section{Bibliography}

Anderson, Margaret Lavinia, Windthorst: A Political Biography (Oxford: Clarendon Press, 1981). Aquinas, Thomas, De Regno ad Regem Cypri: On Kingship to the King of Cyprus, trans. Gerald B. Phelan (Toronto: The Pontifical University of Mediaeval Studies, 1949).

Aquinas, Thomas, Summa Theologica, (New York: Benzinger Brothers, 1947).

Archibald, Katherine, 'The Concept of Social Hierarchy in the Writings of St. Thomas Aquinas' The Historian 12, no. 1, (Fall 1949): 28-54.

Aristotle, Politics, trans. Benjamin Jowett, (Memphis: General Books, 2010).

Barr, Colin, "'Imperium in Imperio": Irish Episcopal Imperialism in the Nineteenth Century', The English Historical Review 123, no. 502, (2008): 611-650.

Belletti, Alberto, ‘Cattolicesimo e Nazionalismo nell’Irlanda di fine Ottocento: La Chiesa e il movimento di Charles Stewart Parnell', (Phd diss., Università di Pisa).

Chadwick, Owen, A History of the Popes, 1830-1914 (Oxford: Oxford University Press, 1998).

Conley, Carolyn A., 'No Pedestals: Women and Violence in Late Nineteenth-Century Ireland', Journal of Social History, 28, no. 4 (Summer, 1995): 802-803.

Farrell, Sean, Rituals and Riots: Sectarian Violence and Political Culture in Ulster, 1784-1886 (Lexington: University of Kentucky Press, 2009).

Holland, Joe, Modern Catholic Social Teaching: The Popes Confront the Industrial Age (Mahwah, N.J.: Paulist Press, 2004).

Larkin, Emmet, 'Socialism and Catholicism in Ireland', Studies: An Irish Quarterly Review, 74, no. 293 (Spring 1998), 57-70.

- The Roman Catholic Church and the Plan of Campaign in Ireland 1886-1888 (Cork University Press: 1978).

- The Roman Catholic Church in Ireland and the Fall of Parnell (University of North Carolina Press: 2011).

Lyons, F.S.L., 'John Dillon and the Plan of Campaign, 1886-90', Irish Historical Studies 14, no. 56 (Sept. 1965): 313-347.

Macaulay, Ambrose, The Holy See, British Policy, and the Plan of Campaign in Ireland, 1885-1893 (Dublin: Four Courts Press, 2002).

Morrissey, Thomas J., William J. Walsh, Archbishop of Dublin, 1841-1921 (Dublin: Four Courts Press, 2000). Privilege, John, Michael Logue and the Catholic Church in Ireland, 1879-1925 (Manchester University Press: 2009).

Murray, John Courtney S.J., 'Leo XIII: Separation of Church and State', Theological Studies 14 (June 
1953): $145-214$.

O’Byrne, Patrick Justin, The Life and Pontificate of Leo XIII (New York: Charles L. Webster, 1903). Phemister, Andrew, “The Surging Tide of Pauper Democracy”: Irish Boycotting and AngloAmerican Liberalism', Radical History Review 134 (2019): 29-57.

Pope Leo XIII, 'Aeterni Patris: On the Restoration of Christian Philosophy', 4 August 1879, trans. Claudia Carlen, The Papal Encyclicals, 1878-1903 (Raleigh, N.C.: McGrath Publishing Company, 1981).

— 'De Rerum Novarum: On Capital and Labour', 15 May 1891.

— 'Diuturnum: On the Origins of the Civil Society', 29 June 1881.

— 'Humanum Genus: On Freemasonry', 20 April 1884.

— 'Immortale Dei: On the Christian Constitution of States' 1 November 1885.

— 'Quod Apostolici Muneris: On Socialism', 28 December 1878

— 'Quod Auctoritate: Proclaiming an Extraordinary Jubilee', 22 December 1885.

— 'Saepe Nos: On Boycotting in Ireland', 24 June 1888.

— 'Sapientiae Christianae: On Christians as Citizens', 10 January 1890.

Thomas, Samuel J. 'The American Press and the Church-State Pronouncements of Pope Leo XIII,' U.S. Catholic Historian 1, no. 1 (Fall, 1980): 17-36.

Tierney, Mark, Croke of Cashel: The Life of Archbishop Tomas William Croke 1823-1902 (Dublin: Gill and Macmillan, 1976).

Tierney, Mark. Croke of Cashel: The Life of Archbishop Thomas William Crooke 1823-1902 (Dublin: Gill and Macmillan, Ltd., 1976).

Trzeciakowski, Lech,'The Prussian State and the Catholic Church in Prussian Poland 1871-1914', Slavic Review 26, no. 4 (December 1967): 618-637.

Urbach, Karina, 'On Her Majesty's Secret Service: Gladstone, Ireland and Pope Leo XIII, 18811885/86' in Vincent Viaene (ed.) The Papacy and the New World Order: Vatican Diplomacy, Catholic Opinion, and International Politics at the Time of Leo XIII, 1878-1903 (Brussels: Institut Historique Belge de Rome, 2005), 181-194.

Walsh, Patrick J., William J. Walsh: Archbishop of Dublin (Dublin: The Talbot Press, 1928). 